\section{An Effective Post-sown Priming Method to Improve Emergence from Lettuce Seeds at High Temperature}

\author{
Ken Takahata ${ }^{1}$, Yoko Mine ${ }^{1}$, Atsukiyo Karimata ${ }^{1}$, and \\ Hiroyuki Miura ${ }^{1,2}$
}

\begin{abstract}
AdDitional INDEX wORDs. Lactuca sativa, plug seedling, seed treatment
\end{abstract}
Summary. A study was conducted to improve the seedling emergence rate of lettuce (Lactuca sativa) seeds at high temperatures using a convenient postsown priming method. Seeding mixtures adjusted to $35 \%, 45 \%$, or $55 \%$ moisture content were sown with lettuce 'Patriot' in cell trays. Postsown priming was performed at $20{ }^{\circ} \mathrm{C}$ for 1 day and at $30^{\circ} \mathrm{C}$ for 3 or 5 days. After the treatment, trays were moved to an emergence room kept at $32.5{ }^{\circ} \mathrm{C}$, a temperature assumed to be typical of non-airconditioned rooms in nurseries. Emergence of nonprimed controls was $9 \%$ to $16 \%$ after 2 days in the emergence room and was $59 \%$ to $75 \%$ on day 6 . In contrast, seedling emergences on day 2 were $95 \%, 76 \%$, and $78 \%$ to $79 \%$ in $55 \%$ moisture at $20{ }^{\circ} \mathrm{C}$ for 1 day, $55 \%$ moisture at $30{ }^{\circ} \mathrm{C}$ for 3 days, and $45 \%$ to $55 \%$ moisture at $30{ }^{\circ} \mathrm{C}$ for 5 days, respectively. Therefore, the treatment with $55 \%$ moisture at $20{ }^{\circ} \mathrm{C}$ for 1 day appeared most effective; however, post-sown priming with $55 \%$ moisture at $30{ }^{\circ} \mathrm{C}$ for 3 days or $45 \%$ to $55 \%$ moisture at $30{ }^{\circ} \mathrm{C}$ for 5 days may be more practical due to lower temperature-control costs. $\longrightarrow$ ell trays for raising vegetable seedlings on a large scale have become increasingly popular because of their low cost; however, the method yields poor emergence rates due to the high temperatures when lettuce seeds are sown in the summer. Inhibition of lettuce seed germination under high temperatures was reported by Gray (1975) who found that germination rates substantially decreased over $22{ }^{\circ} \mathrm{C}$. Therefore, growth chambers which allow to adjust the internal temperature to the optimum temperature are very effective, but high purchase, maintenance, and operating costs limit their use in many agricultural nurseries.

In seed priming, small amounts of water are supplied to seeds so that the water can be taken up through osmotic or matric forces, leading to an activation of numerous seed enzymes. There have been many reports that seed priming before sowing improves the uniformity and rates of lettuce emergence at high ambient temperatures (Cantliffe et al., 1981; Guedes and Cantliffe, 1980; Khan et al., 1990; Taylor et al., 1988); however, seed priming has not been

${ }^{1}$ Department of Agriculture, Tokyo University of Agriculture, Atsugi, 243-0034, Japan

${ }^{2}$ Corresponding author. E-mail miurahvg@ nodai.ac.jp. widely applied in Japan since it re quires advanced technical expertise, and the costs of seed processing by commercial firms are high.

We suppose that priming can be used very efficiently in nurseries where seeds can be sown immediately after the priming step. Miura et al. $(1997,2001)$ attempted to develop an easy and practicable post-sown procedure for priming malabar spinach (Basella alba) and parsley (Petroselinum crispum) seeds, which are not cultivated much in Japan because of low emergence rates.

The present study was conducted to determine the most effective method for post-sown priming of lettuce, one of the very important vegetable crops that are produced in relatively large quantities in Japan.

\section{Materials and methods}

The design of the experiments is shown in Fig. 1. A seeding mixture (Yosaku N-150; Chisso Asahi Fertilizer Co., Tokyo) formulated for raising vegetable seedlings in cell trays was adjusted to $35 \%, 45 \%$, or $55 \%$ moisture content (moisture weight per moist substrate weight) and was evenly distributed into 128-hole cell trays (Landmark Plastic Corp., Akron, $\mathrm{OH}$ ) divided into four sections. One 'Patriot' lettuce seed (Nitto Nosan Seed Co., Yokohama, Japan) was sown $5 \mathrm{~mm}$ deep in each cell. 'Patriot' is a crisphead lettuce type that is sown in the summer in major producing regions. The trays were placed in plastic containers (32 $\mathrm{cm}$ long, $22 \mathrm{~cm}$ wide, $11 \mathrm{~cm}$ high) covered with lids for moisture retention and were kept in a thermostatic room (LH.200; Nippon Medical \& Chemical Instruments Co., Osaka, Japan) at $20{ }^{\circ} \mathrm{C}$ for $1 \mathrm{~d}$ (Expt. 1), at $30{ }^{\circ} \mathrm{C}$ for $3 \mathrm{~d}$ (Expt. 2), or at $30{ }^{\circ} \mathrm{C}$ for $5 \mathrm{~d}$ (Expt. 3). After the treatment, the sectioned trays were watered and transferred to an emergence room $[\mathrm{LH} \cdot 200$; light period $=12 \mathrm{~h}$ per day, mean photosynthetic photon flux $\left.(P P F)=74 \mu \mathrm{mol} \cdot \mathrm{m}^{-2} \cdot \mathrm{s}^{-1}\right] \mathrm{kept}$ at $32.5^{\circ} \mathrm{C}$. The number of seedlings that had emerged more than about 1 mm was checked daily between 0900 to $1000 \mathrm{HR}$, and the fresh weight of the aboveground parts (hypocotyl + epicotyl + cotyledons + leaves) was determined on day 6.

Control groups were set up by sowing nontreated seeds on the days when the post-sown priming was completed for the treated groups and the trays were transferred to the emergence room. Three sectioned trays were used for each of the treated and control groups.

\section{Results}

Emergence on day 1 in Expt. 1 reached $87 \%$ in the $55 \%$ moisture group, followed by the $45 \%$ moisture group at $60 \%$, the $35 \%$ moisture group at $40 \%$, and the control group at $0 \%$ emergence (Fig. 2). The average number of days to emergence (Table 1) was lowest $(1.11 \mathrm{~d})$ in the $55 \%$ moisture group, which also had the highest weight of the aboveground parts with the low coefficient of variation $(\mathrm{CV})$.

\begin{tabular}{llll}
\hline $\begin{array}{l}\text { Units } \\
\text { To convert U.S. to SI, } \\
\text { multiply by }\end{array}$ & U.S unit & SI unit & $\begin{array}{l}\text { To convert SI to U.S., } \\
\text { multiply by }\end{array}$ \\
\hline 2.54 & inch $(\mathrm{es})$ & $\mathrm{cm}$ & 0.3937 \\
25.4 & $\operatorname{inch}(\mathrm{es})$ & $\mathrm{mm}$ & 0.0394 \\
28,350 & $\mathrm{OZ}$ & $\mathrm{mg}$ & $3.5274 \times 10^{-5}$ \\
$\left({ }^{\circ} \mathrm{F}-32\right) \div 1.8$ & ${ }^{\circ} \mathrm{F}$ & ${ }^{\circ} \mathrm{C}$ & $\left(1.8 \times{ }^{\circ} \mathrm{C}\right)+32$
\end{tabular}




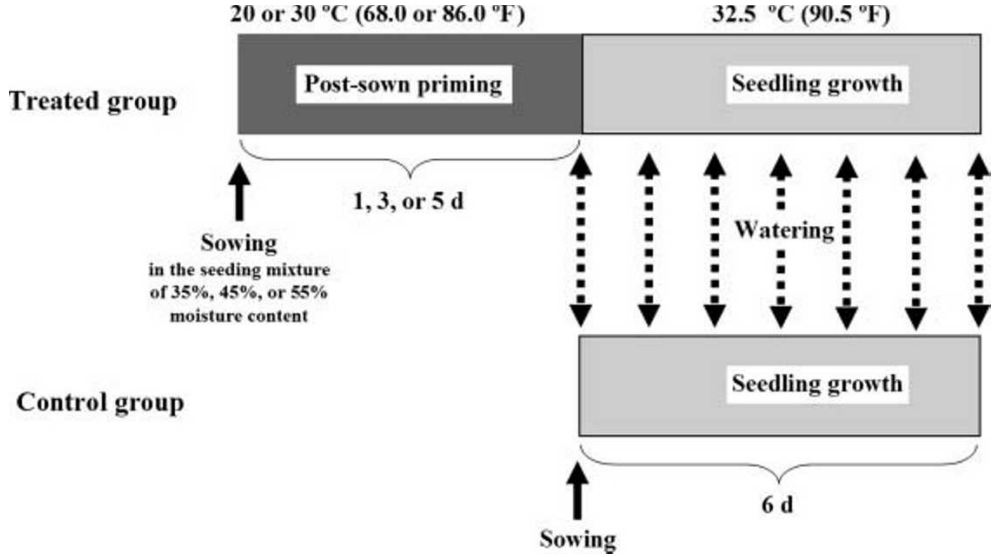

Fig. 1. Procedure of post-sown priming with the seeding mixture followed by seedling growth.

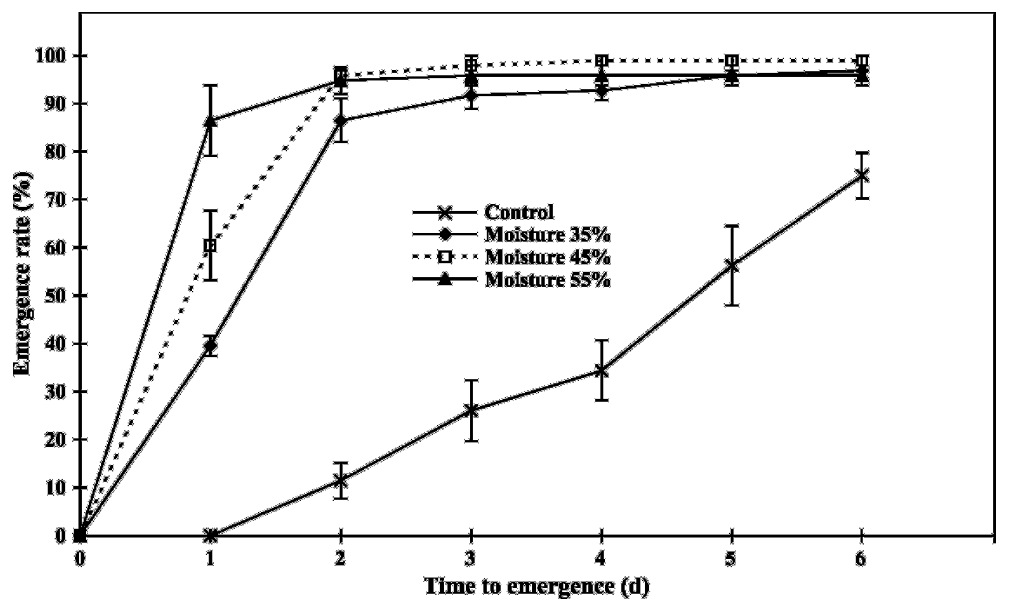

Fig. 2. Effects of post-sown priming with different moisture contents of the seeding mixture at $20^{\circ} \mathrm{C}\left(68.0{ }^{\circ} \mathrm{F}\right)$ for $1 \mathrm{~d}$ on lettuce emergence at $32.5^{\circ} \mathrm{C}\left(90.50{ }^{\circ} \mathrm{F}\right)$ in Expt. 1. Vertical bar $=$ SE.

Table 1. Effect of post-sown priming of lettuce on time to emergence and the fresh weight of the aboveground seedling parts.

\begin{tabular}{llll}
\hline & & \multicolumn{2}{c}{$\begin{array}{c}\text { Fresh wt of aboveground } \\
\text { seedling parts }\end{array}$} \\
\cline { 4 - 5 } Treatment & $\begin{array}{c}\text { Mean time to } \\
\text { emergence }(\mathbf{d})\end{array}$ & $\begin{array}{c}\text { Fresh } \\
\mathbf{w t}(\mathbf{m g})^{\mathbf{z}}\end{array}$ & $\begin{array}{c}\text { Coefficient of } \\
\text { variation (\%) }\end{array}$ \\
\hline Expt. $1\left[20^{\circ} \mathrm{C}\left(68.0^{\circ} \mathrm{F}\right)\right.$ for $\left.1 \mathrm{~d}\right]$ & & & \\
Control & $4.31 \mathrm{a}^{\mathrm{y}}$ & $13.6 \mathrm{c}$ & 48.9 \\
$35 \%$ seeding mixture moisture & $1.81 \mathrm{~b}$ & $25.5 \mathrm{~b}$ & 25.1 \\
$45 \%$ seeding mixture moisture & $1.44 \mathrm{bc}$ & $26.0 \mathrm{~b}$ & 22.5 \\
$55 \%$ seeding mixture moisture & $1.11 \mathrm{c}$ & $28.9 \mathrm{a}$ & 22.6 \\
Expt. 2 [30 ${ }^{\circ} \mathrm{C}\left(86.0^{\circ} \mathrm{F}\right)$ for $\left.3 \mathrm{~d}\right]$ & & & \\
Control & $4.14 \mathrm{a}$ & $14.3 \mathrm{c}$ & 44.5 \\
$35 \%$ seeding mixture moisture & $3.44 \mathrm{~b}$ & $19.8 \mathrm{~b}$ & 45.9 \\
$45 \%$ seeding mixture moisture & $2.37 \mathrm{c}$ & $23.3 \mathrm{a}$ & 22.8 \\
$55 \%$ seeding mixture moisture & $2.05 \mathrm{c}$ & $24.9 \mathrm{a}$ & 18.6 \\
Expt. 3 $\left(30^{\circ} \mathrm{C}\right.$ for $5 \mathrm{~d}$ ] & & & \\
Control & $3.88 \mathrm{a}$ & $18.1 \mathrm{c}$ & 50.8 \\
$35 \%$ seeding mixture moisture & $2.88 \mathrm{~b}$ & $21.2 \mathrm{~b}$ & 40.3 \\
$45 \%$ seeding mixture moisture & $2.16 \mathrm{c}$ & $24.2 \mathrm{a}$ & 20.6 \\
$55 \%$ seeding mixture moisture & $2.08 \mathrm{c}$ & $25.7 \mathrm{a}$ & 14.7 \\
\hline
\end{tabular}

${ }^{\mathrm{z}} 1 \mathrm{mg}=3.5274 \times 10^{-5} \mathrm{oz}$.

y Mean separation by Duncan's multiple range test at $P \leqq 0.05$.
In Expt. 2, emergence was 6\% in the $55 \%$ moisture group on the day the trays were transferred to the emergence room (Fig. 3). Emergence had begun on day 2 in the other groups. On that day, emergence was $9 \%$ in the control, $31 \%$ at $35 \%$ moisture, $59 \%$ at $45 \%$ moisture, and $76 \%$ at $55 \%$ moisture. The $45 \%$ and $55 \%$ moisture groups required the shortest time to emergence and had the greatest aboveground fresh weight (Table l), also with the small $\mathrm{CV}$.

In Expt. 3, some seedlings emerged on day 0 in the $45 \%$ and $55 \%$ moisture groups, with $4 \%$ and $8 \%$ emerging, respectively (Fig. 4). On day 2 , emergence was $16 \%, 56 \%, 79 \%$, and $78 \%$ in the control, and $35 \%$, $45 \%$, and $55 \%$ moisture groups, respectively. The $55 \%$ and $45 \%$ moisture groups performed better with respect to time to emergence as well as the aboveground fresh weight and the low CV (Table 1).

A direct comparison of emergence in the $55 \%$ moisture group of Expt. 2 and the $45 \%$ and 55\% moisture groups of Expt. 3 indicates that there is no significant difference.

Effects of a treatment of $30{ }^{\circ} \mathrm{C} /$ $3 \mathrm{~d} / 55 \%$ moisture on the emergence of four additional cultivars sown in the hot season in Japan were also assessed. On day 2, emergence rates of 'Exceed' (Nitto Nosan Seed Co.), 'Sunny Boy No.l' (Fujii Seed Co., Osaka, Japan), 'Cisco', and 'Berkeley' (Takii \& Company, Kyoto, Japan) were $76 \%, 75 \%, 75 \%$, and $87 \%$, respectively, compared with $18 \%, 12 \%$, $0 \%$, and $14 \%$, respectively, in the control.

\section{Discussion}

Gray (1975) examined germination rates of 22 lettuce cultivars in temperatures ranging from $5{ }^{\circ} \mathrm{C}$ to $33^{\circ} \mathrm{C}$ and found that the optimal temperature for germination was between $15{ }^{\circ} \mathrm{C}$ and $22{ }^{\circ} \mathrm{C}$. The germination rate above this range of temperatures was substantially deduced. Borthwick and Robbins (1928) and Thompson et al. (1979) reported similar findings. In the present study, emergence of 'Patriot' seeds was not synchronous in the control groups at $32.5^{\circ} \mathrm{C}$, which presumably is within the temperature range of noncooled growth rooms during the hot season.

Guedes and Cantliffe (1980), Cantliffe et al. (1981), Taylor et al. 


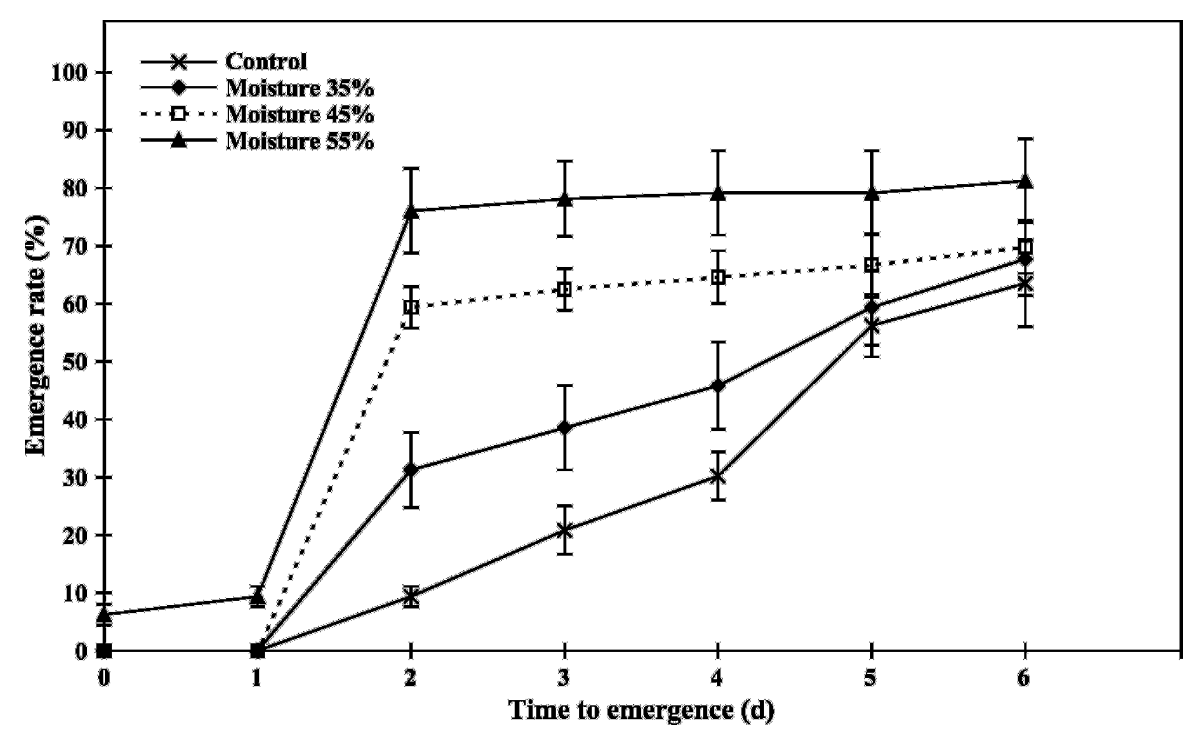

Fig. 3. Effects of post-sown priming with different moisture contents of the seeding mixture at $30{ }^{\circ} \mathrm{C}\left(86.0{ }^{\circ} \mathrm{F}\right)$ for $3 \mathrm{~d}$ on lettuce emergence at $32.5{ }^{\circ} \mathrm{C}\left(90.50{ }^{\circ} \mathrm{F}\right)$ in Expt. 2. Vertical bar $=$ SE.

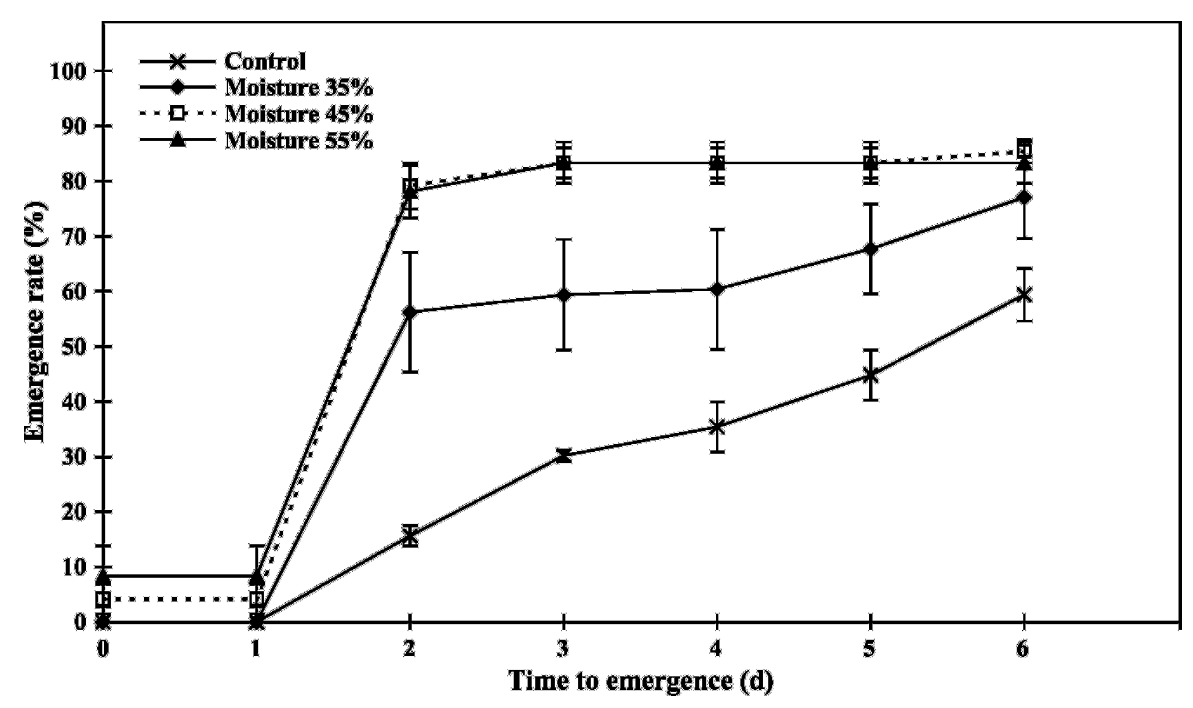

Fig. 4. Effects of post-sown priming with different moisture contents of the seeding mixture at $30{ }^{\circ} \mathrm{C}\left(86.0{ }^{\circ} \mathrm{F}\right)$ for $5 \mathrm{~d}$ on lettuce emergence at $32.5{ }^{\circ} \mathrm{C}\left(90.50{ }^{\circ} \mathrm{F}\right)$ in Expt. 3. Vertical bar $=$ SE.

(1988), and Khan et al., (1990), respectively, reported that tripotassium phosphate, polyethylene glycol, ground shale, and synthetic calcium silicate were effective for priming. These priming treatments require high levels of technical expertise, and seeds usually are treated by professional seed processors before being sown at agricultural nurseries.

Post-sown priming for 'Patriot' seeds with a seeding mixture was most mixtures. Thus, moisture contents can be easily adjusted.

Cost factors are important for evaluating the economy of cell tray seeding. Taking into account the costs of temperature control units capable of lowering the temperature to $15{ }^{\circ} \mathrm{C}$ to $20{ }^{\circ} \mathrm{C}$ in agricultural facilities, $30{ }^{\circ} \mathrm{C} / 3 \mathrm{~d} / 55 \%$ moisture and $30{ }^{\circ} \mathrm{C} / 5 \mathrm{~d} / 45 \%$ to $55 \%$ moisture appear preferable to $20{ }^{\circ} \mathrm{C} / 1 \mathrm{~d} / 55 \%$ moisture. It is noteworthy that these treatments improved emergence on day 6 under $32.5^{\circ} \mathrm{C}$ to about $80 \%$, a level satisfactory for commercial lettuce production.

\section{Literature cited}

Borthwick, H.A. and W.W. Robbins. 1928. Lettuce seed and its germination. Hilgardia 3:275-305.

Cantliffe, D.J., K.D. Shuler, and A.C. Guedes. 1981. Overcoming seed thermodormancy in a heat sensitive romaine lettuce by seed priming. HortScience 16:196-198.

Gray, D. 1975. Effects of temperature on the germination and emergence of lettuce (Lactuca sativa L.) varieties. J. Hort. Sci. 50:349-361.

Guedes, A.C. and D.J. Cantliffe. 1980. Germination of lettuce seeds at high temperature after seed priming. J. Amer. Soc. Hort. Sci. 105:777-781.

Khan, A.A., H. Miura, J. Prusinki, and S. Ilyas. 1990. Matriconditioning of seeds to improve emergence. Proc. Natl. Symp. Stand Establishment Hort. Crops. p. $19-40$.

Miura, H., Y. Yamato, M. Hamano, and H. Yamazaki. 2001. Improvement of emergence of parsley seeds by post-sown priming. J. Jpn. Soc. Hort. Sci. 70:665668.

Miura, H., H. Yamazaki, and T. Nishijima. 1997. Post-sown priming with a potting mixture to improve emergence of malabar spinach, Basella alba L. J. Jpn. Soc. Hort. Sci. 66:513-517.

Taylor, A.G., D.E. Klein, and T.H. Whitlow. 1988. SMP: Solid matrix priming of seeds. Scientia Hort. 37:1-11.

Thompson, P.A., S.A. Cox, and R.H. Sanderson. 1979. Characterization of the germination responses to temperature of lettuce (Lactuca sativa L.) achenes. Ann. Bot. (Lond.) 43:319-334. 